\title{
Experiments on Hybrid Precast Concrete Shear Walls Emulating Monolithic Construction with Different Amounts of Posttensioned Strands and Different Debond Lengths of Grouted Reinforcements
}

\author{
Zhangfeng $\mathrm{Zhu}^{1}$ and Zhengxing Guo ${ }^{2}$ \\ ${ }^{1}$ College of Civil Engineering, Nanjing Tech University, Nanjing, China \\ ${ }^{2}$ School of Civil Engineering, Southeast University, Nanjing, China \\ Correspondence should be addressed to Zhangfeng Zhu; zzfking2210@163.com
}

Received 21 May 2016; Accepted 9 October 2016

Academic Editor: Akihiko Kimura

Copyright (C) 2016 Z. Zhu and Z. Guo. This is an open access article distributed under the Creative Commons Attribution License, which permits unrestricted use, distribution, and reproduction in any medium, provided the original work is properly cited.

\begin{abstract}
This paper proposed a hybrid precast concrete shear wall emulating monolithic construction (HPWEM) that utilized grouted vertical connecting reinforcements and unbonded posttensioned high-strength strands across the horizontal joint for the lateral resistance. The grouted reinforcements with predetermined debond length were used to provide strength by tension and energy dissipation by yielding. The posttensioned strands were mainly employed to offer the restoring force to reduce the residual displacement by elastic extension. The overlapping welded closed stirrups improved the confinement property of the restrained concrete, avoiding the brittle failure. Six HPWEM specimens, considering variables including the amounts of strands and the debond lengths of grouted reinforcements, as well as one referenced cast-in-place monolithic wall specimen, were tested under the low-cycle reversed lateral load. The HPWEM specimens were capable of providing strength, stiffness, ductility, and energy dissipation equivalent to that of the monolithic wall specimen under certain variable condition.
\end{abstract}

\section{Introduction}

Precast concrete walls have been continuously investigated by many researchers and the earliest research can trace to the PREcast Seismic Structural Systems (PRESSS) Research Program in the early 1990s [1]. Tests on mild steel connection and prestressed connection for horizontal joints of precast walls by Soudki et al. indicated that, with respect to mild steel connection, the prestressed connection exhibited evident self-centering capacity but poorer energy-dissipating capacity $[2,3]$. Hybrid precast concrete wall system, utilizing a combination of mild steel and unbonded posttensioned steel passing through horizontal joint as lateral resistance system in seismic zones, has been studied previously [4, 5]. The desirable properties such as self-centering character and energy dissipation performance were verified in the completed experimental and analytical work $[6,7]$. Moreover, supplemental viscous damping was applied in the hybrid system to enhance the energy dissipation capacity [8]. However, the hybrid precast wall system falls outside the specified monolithic concrete structural system according to ACI 31811 [9] and thus there always have been significant limitations existing on the engineering application of hybrid precast walls in seismic regions. On the other hand, due to the fact that concrete is discontinuous across the horizontal joint, the elastic lateral performance of emulative precast concrete walls, such as anticrack capacity, has been obviously reduced compared with monolithic walls.

In this paper, hybrid precast concrete shear walls emulating monolithic construction (HPWEM) are presented. The key features of HPWEM are as follows (as shown in Figure 1):

(1) The unbonded posttensioned multistrand tendons are placed in the PVC duct embedded in the center of the precast wall panel to delay cracking at small 


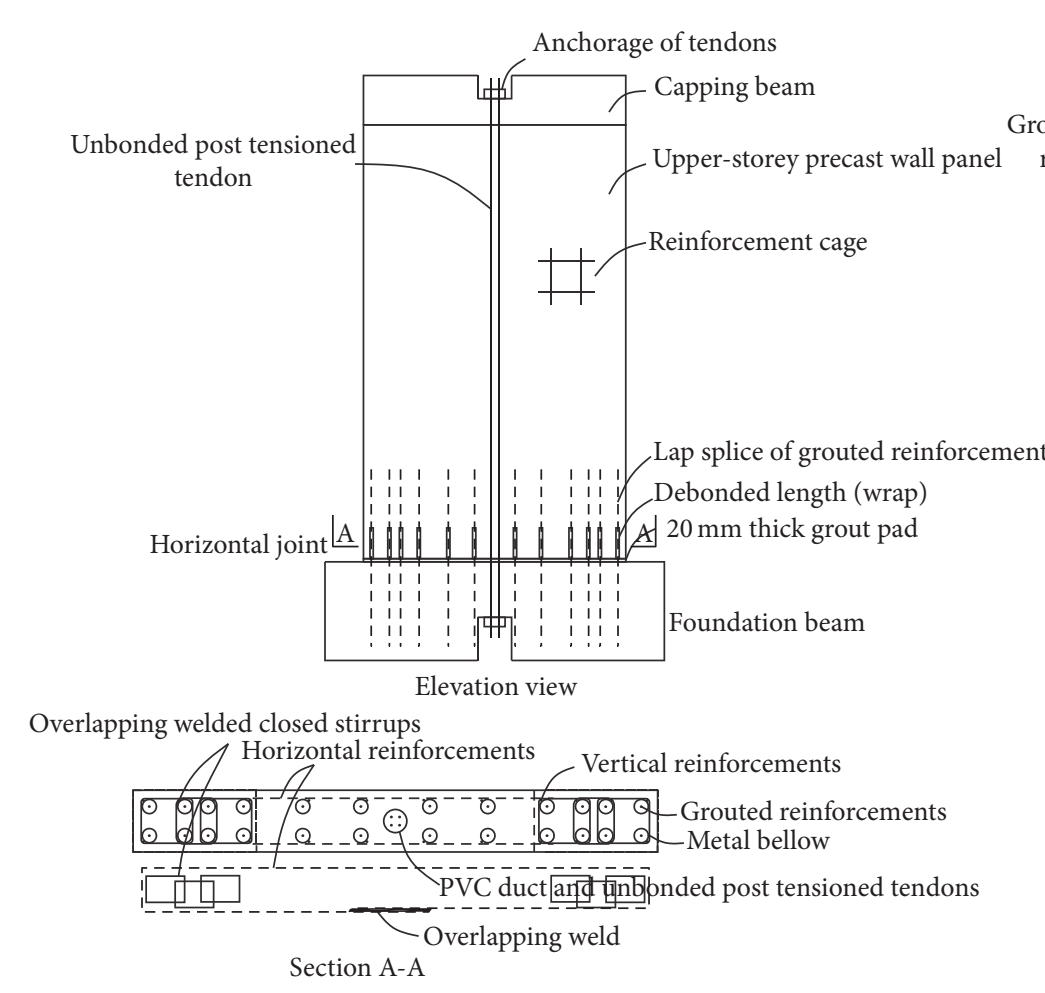

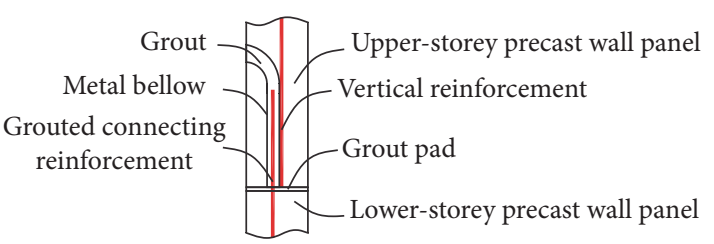

Lap splice connection

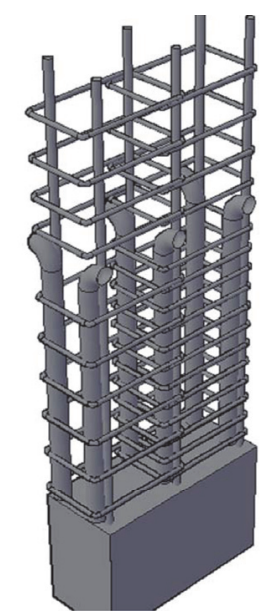

3D diagram of horizontal connection

FIGURE 1: General features of HPWEM.

lateral drift stage, decrease residual displacement, and enhance force capacity at large lateral drift stage.

(2) The vertical connecting reinforcements are protruded from the foundation or the lower-storey precast wall panel and grouted in the metal bellows embedded adjacent to vertical reinforcements of the reinforcement cage in the upper-storey precast wall panel and that formed overlapping connection of the vertical load-bearing reinforcements. The strength grade and diameter of the grouted reinforcements are identical with the vertical reinforcements of the reinforcement cage. In addition, a predetermined length of these reinforcements is debonded above the joints (by wrapping the reinforcements with plastic films) to limit the steel strains and prevent low-cycle fatigue fracture. These grouted connection reinforcements anchored on both sides of the horizontal joint are designed to yield in tension and compression and provide flexural capacity as well as energy dissipation under lateral load into the nonlinear range.

(3) The horizontal reinforcement in the precast wall panel is fabricated from single steel bar, enclosing the confinement cage at both wall toes, and overlap welded near the middle of the panel to ensure the reinforcement effectiveness and also strengthen concrete constraint property.

(4) The stirrups with limited length-to-diameter aspect ratio are placed in both wall toes. The stirrups are closed by overlapping weld, placed surrounding four vertical reinforcements and overlapped against each other through co-used two vertical reinforcements. The overlapped welded closed stirrups can improve the confinement property of the concrete more effectively.

With respect to HPWEM, the specific project objectives in this paper are mainly to develop (1) experimental evidence demonstrating the emulative monolithic performance of the specimens under cyclic lateral force; (2) validated analytical models by ABAQUS; (3) the impact of different amounts of strands and different debond lengths of grouted reinforcements on lateral performance of the specimens.

\section{Research Significance}

Precast concrete structure was wildly used due to its highquality production, fast erection, and relatively economic benefit. Emulative and hybrid precast concrete wall system were continuously researched and developed in the last few decades. However, significant limitations existed in their practical use in seismic zones according to current standards. HPWEM combining emulative and hybrid wall concepts should be capable of performing exactly consistent with, even better than cast-in-situ monolithic wall. The authors believe that the proposed wall has competitive advantage and the research achievement will be very useful to precast concrete technology. 
TABLE 1: Tensile properties of steel materials.

\begin{tabular}{|c|c|c|c|c|}
\hline Characteristics & $15.24 \mathrm{~mm}$ diameter posttensioned strand & 16 diameter bar & 10 diameter bar & 8 diameter stirrup \\
\hline Area, $\mathrm{mm}^{2}\left(\right.$ in. $\left.^{2}\right)$ & $140(0.22)$ & $201.1(0.31)$ & $78.5(0.12)$ & $50.3(0.08)$ \\
\hline Yield strength, MPa (ksi) & $1650(239.25)$ & $438(63.51)$ & $430(62.35)$ & $451(65.4)$ \\
\hline Strain at yield strength, $\%$ & 0.85 & 0.31 & 0.36 & 0.43 \\
\hline Peak strength, $\mathrm{MPa}(\mathrm{ksi})$ & $2050(297.25)$ & $620(89.9)$ & $557(80.77)$ & $618(89.61)$ \\
\hline Strain at peak strength, $\%$ & 5.6 & 15 & 12 & 7.7 \\
\hline Elongation, \% & 5.6 & 19 & 14.3 & 10.8 \\
\hline
\end{tabular}

\section{Experimental Investigation}

Seven full scale wall specimens consisting of one reference cast-in-place monolithic wall specimen and six HPWEM specimens were investigated in this paper. All the specimens were tested under reversed cyclic lateral loading. Hysteretic behavior, load-carrying capacity, stiffness degradation, ductility, energy dissipation, and residual displacement of HPWEM specimens were obtained by contract to the monolithic specimen. The design variables including the amounts of posttensioned strands and debond length of grouted mild steel reinforcements were considered in the experiment.

3.1. Materials. The plain concrete of strength grade C35 (i.e., the cubic compressive strength was $35 \mathrm{MPa}$ [5.08 ksi]) were specified for all specimens. Three groups of nine cubes with side length $150 \mathrm{~mm}$ (5.91 in.) were fabricated and tested 28 days later. The statistic compression strength from the test results was $35.38 \mathrm{MPa}$ (5.17 ksi).

The nonshrink, high-strength, and cement-based grout was used in the metal bellows and grout pad. The measured compressive strength of cylinders with $100 \mathrm{~mm}$ (3.94 in.) side length and $200 \mathrm{~mm}$ (7.87 in.) high was $60 \mathrm{MPa}(8.77 \mathrm{ksi})$. Moreover, in order to ensure the quality of grouting construction, the flow ability of the grout is required to be no less than $290 \mathrm{~mm}$ (11.42 in.) and the measured fluidity was $300 \mathrm{~mm}$ (11.81 in.).

Three samples of both steel strands and reinforcements incorporated in specimens were pulled and the average tensile properties are summarized in Table 1 . Note that the posttensioned strand and stirrup bar possessed no obvious yield plateau and their yield strength was taken as the proportional limit and the stress corresponding to a plastic strain of $0.2 \%$, respectively.

3.2. Specimens. One monolithic and six HPWEM specimens were investigated. All specimens were tested at full scale with consistent wall geometry of thickness $200 \mathrm{~mm}$ (7.87 in.), length $1700 \mathrm{~mm}$ (66.93 in.) and height $3620 \mathrm{~mm}$ (142.52 in.). A foundation beam of height $640 \mathrm{~mm}$ (25.2 in.), width $700 \mathrm{~mm}$ (27.56 in.) and length $2200 \mathrm{~mm}$ (86.61 in.) was used to simulate structural base. In addition, a capping beam of height $320 \mathrm{~mm}$ (12.6 in.), width $240 \mathrm{~mm}$ (9.45 in.) and length $1700 \mathrm{~mm}$ (66.93 in.) were fabricated on the top of the wall for connecting the hydraulic jack.

The reinforcement details of the monolithic wall specimen (referred to as Specimen MW) are shown in Figure 2.
The concrete cover depth was $15 \mathrm{~mm}$ (0.59 in.). Eight reinforcements of diameter $16 \mathrm{~mm}$ ( $0.63 \mathrm{in}$.) were placed within the boundary elements at both wall toes and eight reinforcements of diameter $10 \mathrm{~mm}$ (0.39in.) were embedded in the middle of the wall. Distributed horizontal reinforcements were arranged through the entire wall height at space of $200 \mathrm{~mm}$ (7.87 in.) and had overlapping welded joints near the center of the wall. Stirrups of diameter $8 \mathrm{~mm}(0.31 \mathrm{in}$.) with 135 hooks were placed in the boundary elements at both wall toes at space of $100 \mathrm{~mm}$ (3.94 in.).

The reinforcement details of HPWEM specimens (referred to as Specimens HPWEM1-5) were generally identical to Specimen XJ, except for the following as shown in Figure 3:

(1) The vertical reinforcements crossing the horizontal joint were anchored in grouted metal bellows embedded adjacent to the vertical reinforcements in the wall and that provided lap splice connection for continuity of the reinforcements as shown in Figure 1. The vertical reinforcements protruded $600 \mathrm{~mm}$ (23.62 in.) from the top of the foundation beam. Moreover, the reinforcements were wrapped by plastic film according to the predetermined debond lengths.

(2) Certain amounts of high-strength strands of diameter $15.2 \mathrm{~mm}$ (0.6 in.) were placed in embedded PVC duct of diameter $75 \mathrm{~mm}$ ( $2.95 \mathrm{in}$.) and passed through the wall panel, external beam, and the foundation beam.

(3) Stirrups with 135 hooks were replaced by overlapping welded closed stirrups as shown in Figure 1. Moreover, the space of exterior welded closed stirrups was reduced to $50 \mathrm{~mm}$ (1.97 in.). follows:

The construction progress of HPWEM specimens was as

(1) The steel shims with $20 \mathrm{~mm}$ ( $0.79 \mathrm{in}$.) thickness were uniformly placed on the top of the foundation beam along the cross section of the shear wall to adjust the construction elevation and form the gap for the grout layer.

(2) The precast wall panel was then erected and temporarily fixed on the foundation beam and the connection reinforcements were also inserted into the metal bellows.

(3) The wood molding was set up around the grout layer.

(4) The grout was poured into the metal bellows and the grout layer under the effect of gravity from 


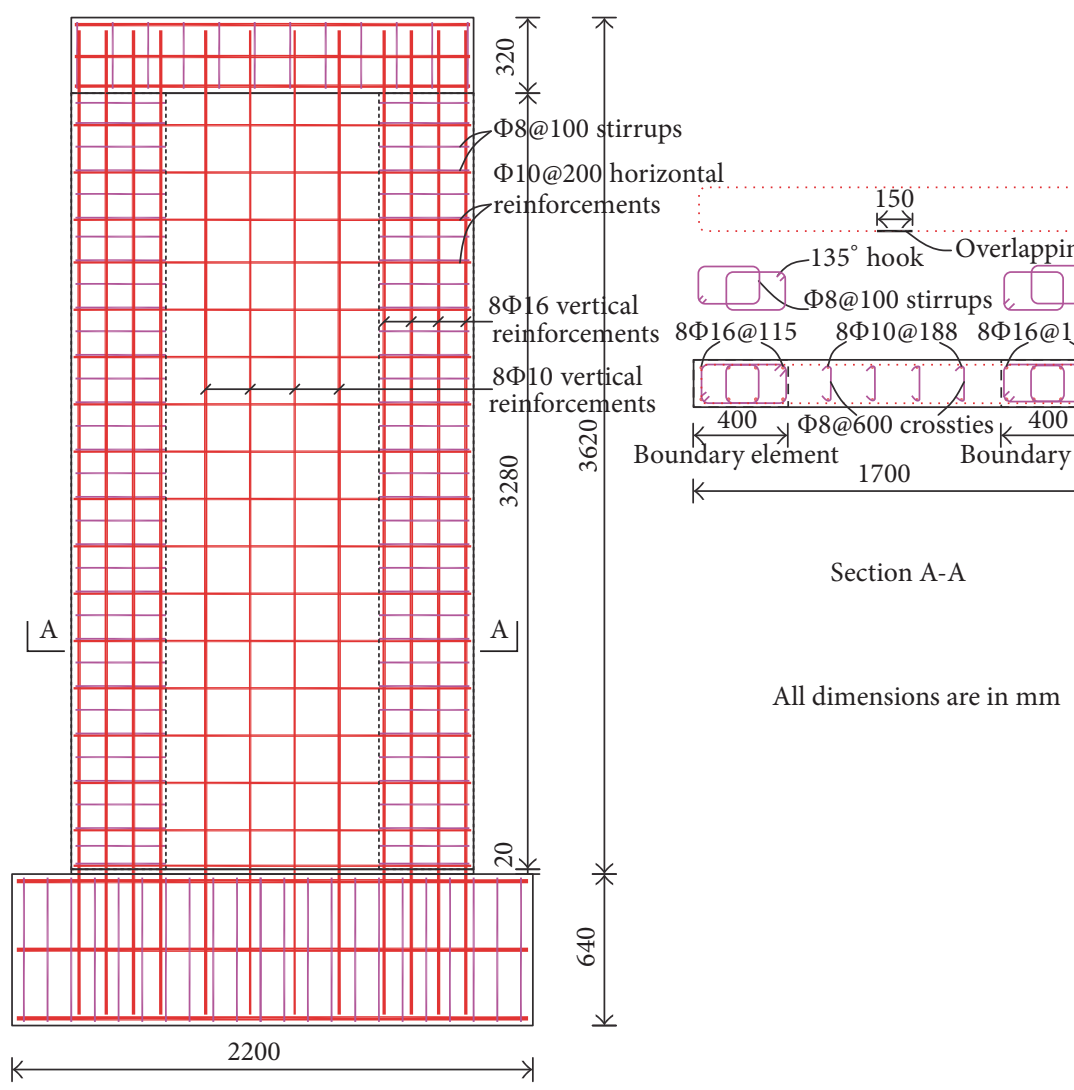

FIgURE 2: Details of the monolithic wall specimen.

the location about $1000 \mathrm{~mm}$ (39.37 in.) higher than the grout inlet. The bellows were grouted one by one while the grout outflowed from the working inlet. Once all the bellows were grouted, the supplying grout was essential to ensure the compactness of the grout.

(5) Once the grout was maintained to its design strength, the high-strength strands were placed into the duct and then posttensioned and anchored on the specimen. Thus, the fabrication of HPWEM specimen was finished.

Moreover, different amounts of posttensioned strands as well as different debond lengths of grouted reinforcements were considered in the test. The list of important features of all specimens is provided in Table 2 .

3.3. Test Setup. The overall test setup is shown in Figure 4. The specimens were fixed to the ground floor of the laboratory by eight high-strength thread steel bars (the design yield strength $f_{p y k}=1080 \mathrm{MPa}[156.6 \mathrm{ksi}]$ ) of diameter $32 \mathrm{~mm}$ (1.26 in.). Each bar was posttensioned with an internal force of $200 \mathrm{kN}$ (44.96 kips) to eliminate the horizontal slip between specimen and ground floor under lateral load. Meanwhile, four triangle truss braces were used to prevent the out-ofplane overturn and in-plane torsion of test specimen. A $1000 \mathrm{kN}$ capacity hydraulic jack was installed on the reaction wall and connected the specimen through external beam for the application of the lateral load. The lateral load was applied at a distance of $3.46 \mathrm{~m}(11.35 \mathrm{ft})$ from the top of the foundation beam, and thus the shear span ratio was calculated as 2 . In addition to the self-weight of the wall [31 kN (6.97 kips)], an external axial load of approximately $946 \mathrm{kN}$ (212.67 kips) was applied on the top of external beam (resulting in a total axial load ratio of 0.12 ). A load device consisted of one distributive steel girder, two $1000 \mathrm{kN}$ capacity hydraulic jacks, and eight high-strength strands (Grade 1860) of diameter $15.2 \mathrm{~mm}(0.6 \mathrm{in}$.) were used for the application of the vertical load.

The load history consisted of force and displacement cycles as shown in Figure 5. The first stage was controlled by force with one cycle at each increment and the subsequent stage was controlled by displacement with three cycles at each increment of $23 \mathrm{~mm}$ (0.91 in.).

3.4. Items of Investigation. The measurement system used in this experiment included 54 channels of data with 6 displacement transducers, 4 load cells, and 44 strain gauges. The displacement transducers were used to measure the inplane displacements of the wall panel. The load cells were used to measure the applied lateral load, the vertical force simulating service-level gravity loads on the wall, and the force in unbonded posttensioned strands. The strain gauges were used to measure the strain of the grouted reinforcements. 


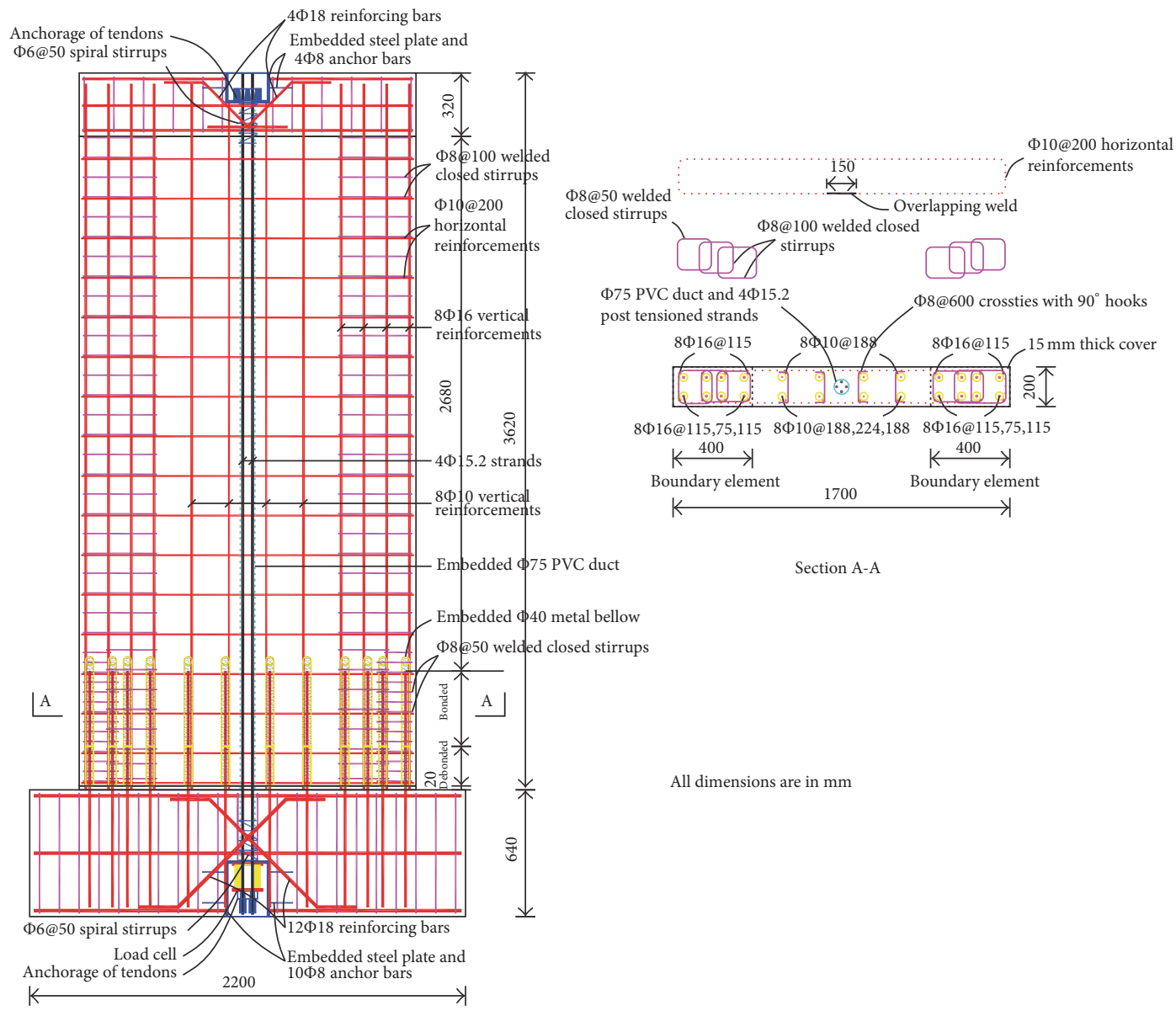

FIGURE 3: Details of HPWEM specimens.

\section{Analytical Investigation}

The finite element model (FEM) was established using ABAQUS to capture the general behavior of HPWEM specimens as can be seen in Figure 6(a). The 8-node, firstorder, reduced-integration, solid elements C3D8R were used to simulate concrete behavior and the 2-node linear 3D truss elements T3D2 were used to model the reinforcements and posttensioned tendons. The damaged plasticity concrete behavior (Figure 6(b)) and idealized multilinear elastoplastic behavior (Figure 6(c)) were incorporated in the constitutive models for concrete and steel, respectively. The mechanical model at the wall-to-foundation-beam joint assumed the default "hard" contact in the normal direction that can simulate the open/close behavior of the horizontal joint and "rough" friction and finite sliding in the tangential direction. Meanwhile, the bond-slip behavior between concrete and reinforcement was ignored in the model.

\section{Experimental and Analytical Results}

5.1. Cracking Pattern and Failure Mode. The observations made during the test sequence are summarized in Table 3 and the failure modes were shown in Figure 7. As indicated in Table 3 , the base shear force $\left(V_{b}\right)$ was precisely equal to the applied lateral load and the wall drift $\left(\Delta_{w}\right)$ was calculated as the ratio between lateral displacement of the wall at the load point and the height from the top of the foundation beam to the load point. Consistent with the design intension, the crack initialed later in HPWEM specimens than in MW specimen. The debond configuration of grouted reinforcements offset the horizontal crack more or less upward from the bottom of the wall. The offset value was discrete and had no direct relationship with the debond length and that could be due to the uncontrollable material property of the concrete, especially the tensile strength. Due to the enhanced confinement property resulted from the overlapping welded closed stirrups, the concrete crushed at lager displacement in HPWEM specimens than in MW specimen and the concrete damage at wall toes was obviously limited.

5.2. Hysteretic Behavior. The $V_{b}-\Delta_{w}$ relations for the tested specimens are shown in Figure 8. All the specimens exhibited stable load versus drift hysteretic response and the shape of all hysteretic curves for all the specimens were similar to each other. The similar, minor pinching effect, mainly resulted from diagonal cracking in the wall, could be observed in the hysteretic loops of all the specimens, and thus good energydissipating capacity was indicated for all the specimens. 


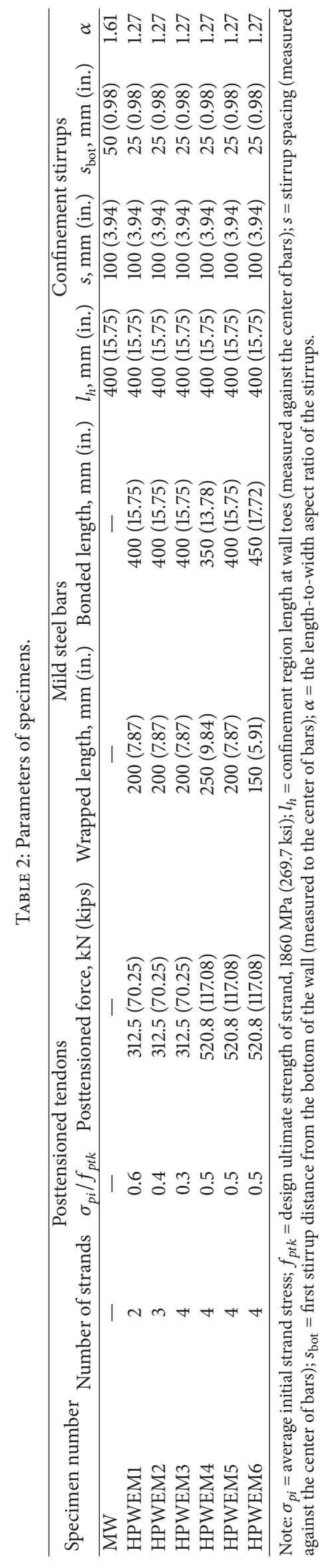




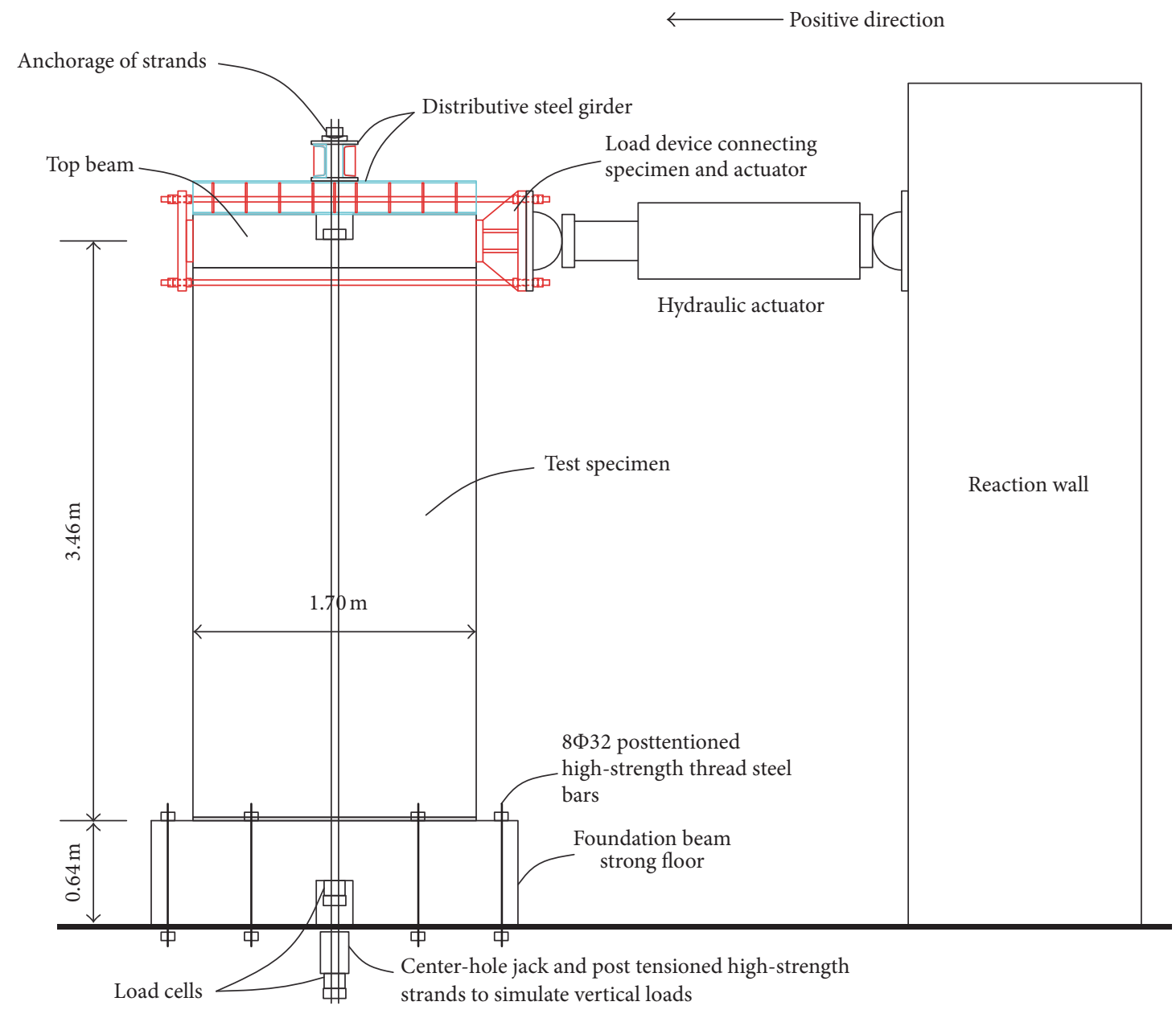

Figure 4: Test setup.

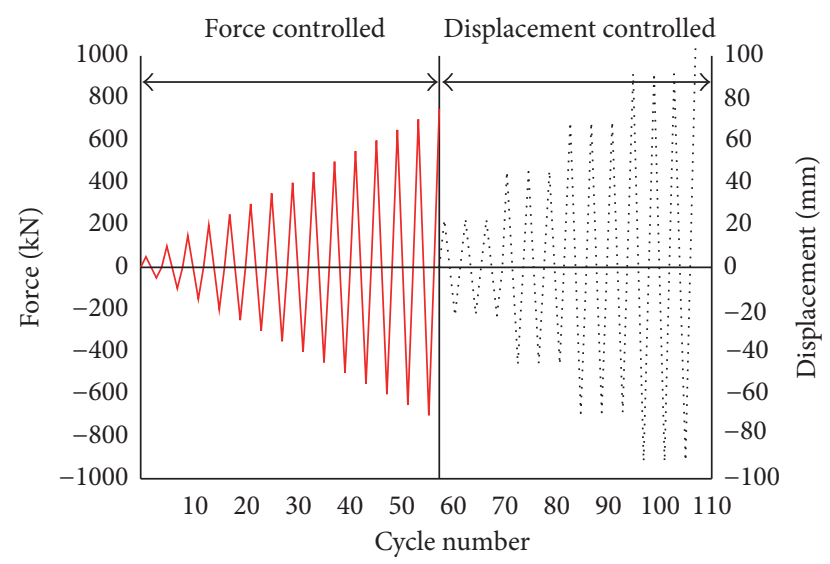

Figure 5: Load history. $(1 \mathrm{kN}=0.22 \mathrm{kips}, 1 \mathrm{~mm}=0.04 \mathrm{in}$. $)$

Besides, the predicted $V_{b}-\Delta_{w}$ relationship curves in positive direction for the specimens using ABAQUS models are also appended in Figure 8. The analytical results provided a reasonable match to the envelope of the measured $V_{b}-\Delta_{w}$ curves of the specimens. The measured and analyzed peak loads were annotated in Figure 8, and the deviations between them were controlled by $\pm 6 \%$ at most.
5.3. Strength. The ultimate load-carrying capacities of the specimens in the positive and negative directions are shown in Figure 9. HPWEM specimens obtained visually larger strength than the MW specimen, probably due to the presence of high-strength strands. With regard to the influence of the amount of strands, by comparing specimens HPWEM13 , the strength of HPWEM specimen was slightly enhanced (by up to $4 \%$ based on average results in positive and negative directions as shown in Figure 9) as the number of strands was increased. Similarly, by comparing specimens HPWEM4-6, the decrease of the debond length enhanced the strength by up to $5 \%$. Meanwhile, in consideration of specimens HPWEM 3 and HPWEM5 (only the posttensioned force in the unbonded tendon was different among them), the strength of HPWEM specimen was relatively obviously affected by the initial posttensioned stress in the strands, probably based on the direct impact on the ultimate stress in the strands.

5.4. Stiffness Degradation. The lateral stiffness was defined as the secant stiffness which was calculated as the slope of the line connecting the peak load response in the positive and negative directions during a loading cycle. The stiffness changes throughout the test are plotted in Figure 10. 


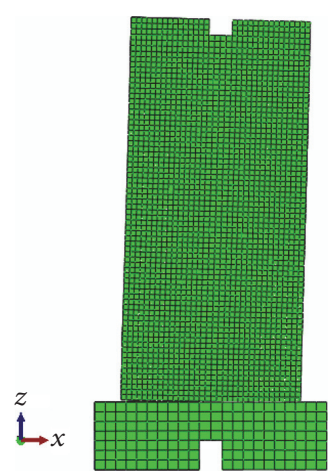

(a) FEM

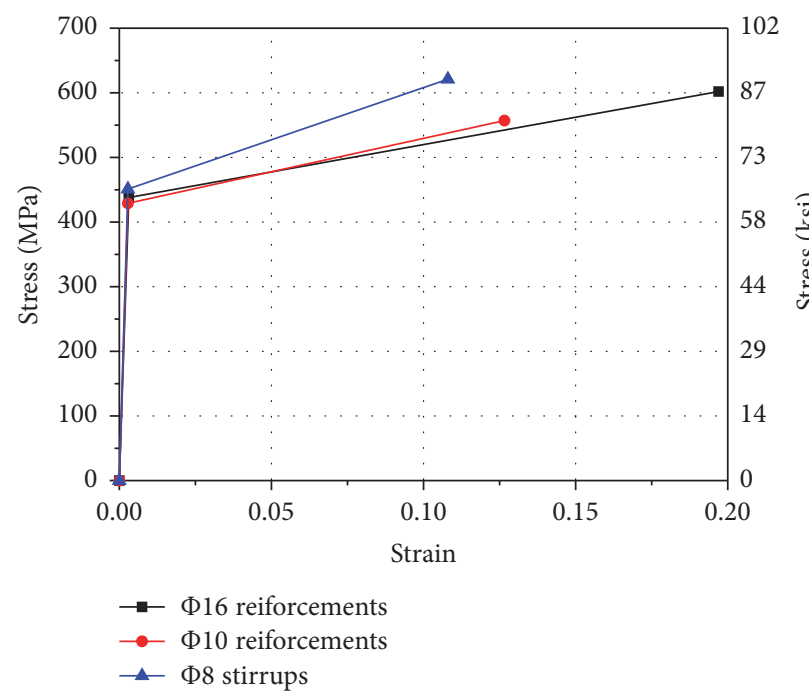

(c) Constitutive model for mild steel

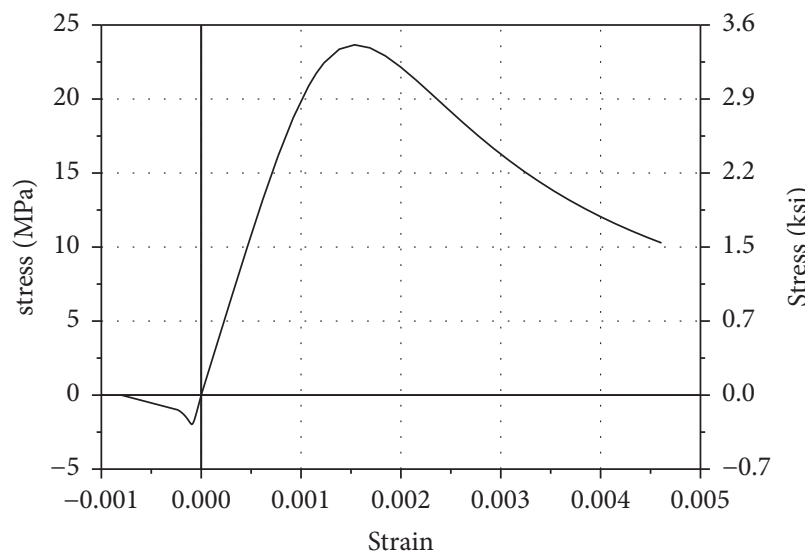

(b) Constitutive model for concrete

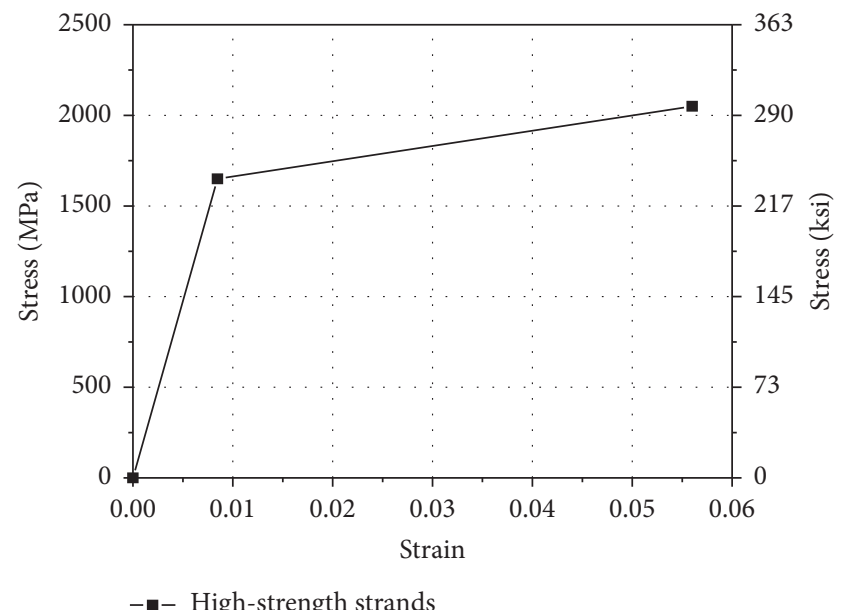

(d) Constitutive model for strand steel

FIGURE 6: Finite element modeling.

TABLE 3: Test observations of the specimens.

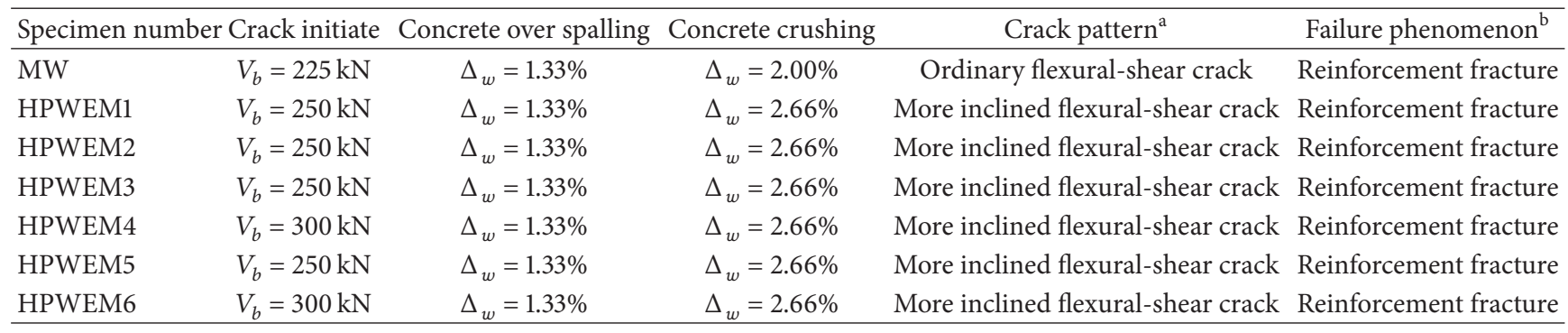

Note: $1 \mathrm{kN}=0.22$ kips.

${ }^{a}$ The slant degrees of the diagonal crack of Specimens HPWEM1-6 were compared with Specimen MW.

${ }^{\mathrm{b}}$ Unlike Specimen MW, the reinforcement fracture occurred by axial tension as well as torsion shear resulted from unavoidable minimal out-of-plane torsion during large lateral displacement stage.

For clarity, the stiffness of the elastic status, the cracking status, and the first cycle during each displacement loading increment were selected to illustrate the stiffness degradation process of the specimens. HPWEM specimens showed better stiffness than MW specimen, especially in the initial stage. Moreover, the elastic stiffness was most related to the posttensioned force established in the unbonded tendons, which could be found by comparing specimens HPWEM13 with specimens HPWEM4-6. Meanwhile, the decrease of the debond length of the connecting reinforcements also 


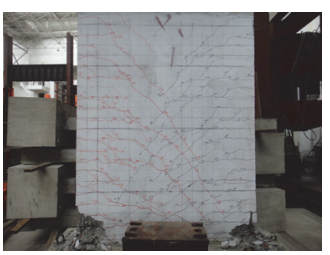

(a) MW
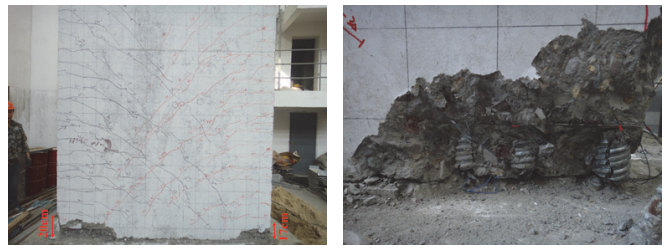

(c) HPWEM2
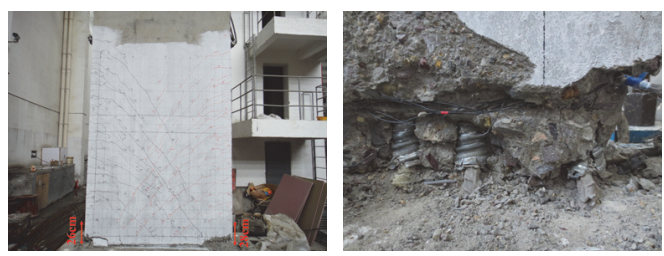

(e) HPWEM4
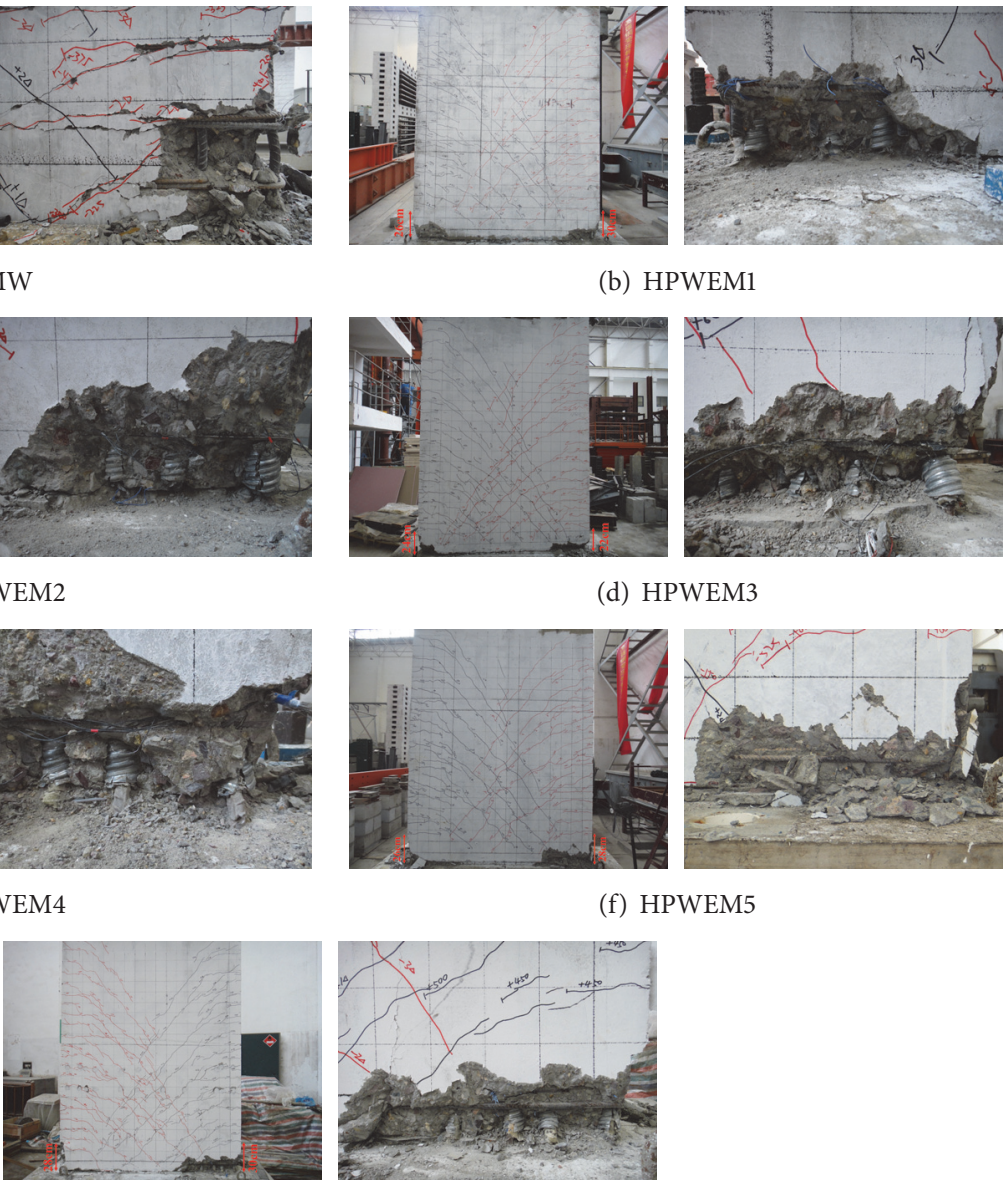

(b) HPWEM1
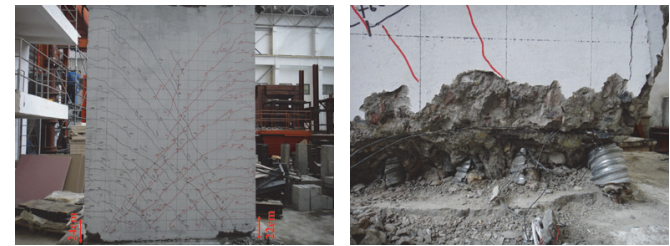

(d) HPWEM3
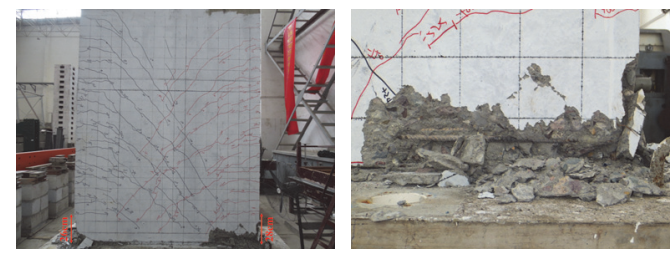

(f) HPWEM5

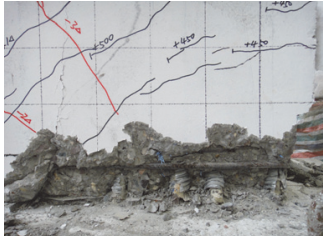

(g) HPWEM6

FIGURE 7: Failure modes.

TABLE 4: Displacement ductility of the specimens.

\begin{tabular}{|c|c|c|c|c|c|c|c|}
\hline \multirow[t]{2}{*}{ Specimen } & \multicolumn{2}{|c|}{$\begin{array}{c}\text { Yield displacement } \\
\Delta_{y}(\mathrm{~mm})\end{array}$} & \multicolumn{2}{|c|}{$\begin{array}{l}\text { Ultimate displacement } \\
\qquad \Delta_{u}(\mathrm{~mm})\end{array}$} & \multicolumn{2}{|c|}{$\begin{array}{l}\text { Displacement ductility } \\
\text { factor }(\mu)\end{array}$} & \multirow[t]{2}{*}{$\begin{array}{c}\text { Average displacement } \\
\text { ductility factor }(\mu)\end{array}$} \\
\hline & Positive & Negative & Positive & Negative & Positive & Negative & \\
\hline MW & 27.3 & -39.7 & 92.4 & -94.2 & 3.38 & 2.37 & 2.875 \\
\hline HPWEM1 & 27.5 & -32.9 & 94.2 & -94.0 & 3.43 & 2.86 & 3.145 \\
\hline HPWEM2 & 28.5 & -34.1 & 93.3 & -94.3 & 3.27 & 2.77 & 3.02 \\
\hline HPWEM3 & 32.4 & -30 & 92.2 & -92.2 & 2.85 & 3.07 & 2.96 \\
\hline HPWEM4 & 31.6 & -44.2 & 93.5 & -92.5 & 2.96 & 2.09 & 2.525 \\
\hline HPWEM5 & 31.2 & -44.5 & 92.9 & -93.1 & 2.98 & 2.09 & 2.535 \\
\hline HPWEM6 & 31.0 & -37.7 & 94.3 & -91.2 & 3.04 & 2.42 & 2.730 \\
\hline
\end{tabular}

Note: $1 \mathrm{~mm}=0.04$ in.

slightly enhanced the initial stiffness of the specimen. Besides, the stiffness of HPWEM specimens was close to each other during the displacement loading stage.

5.5. Displacement Ductility. The average displacement ductility in the positive and negative directions is listed in Table 4 . The yield displacement was found by extrapolating the measured stiffness at $75 \%$ of the theoretical flexure strength of the specimen up to the theoretical strength of the specimen [10], and the measured peak lateral displacement was set as the ultimate displacement. Specimens HPWEM13 exhibited better ductility than Specimen MW; however, specimens HPWEM4-6 performed poorer than Specimen MW. It was apparent that the posttensioned force in the unbonded strands had evident impact on the ductility of HPWEM specimens. Moreover, by comparing Specimens 


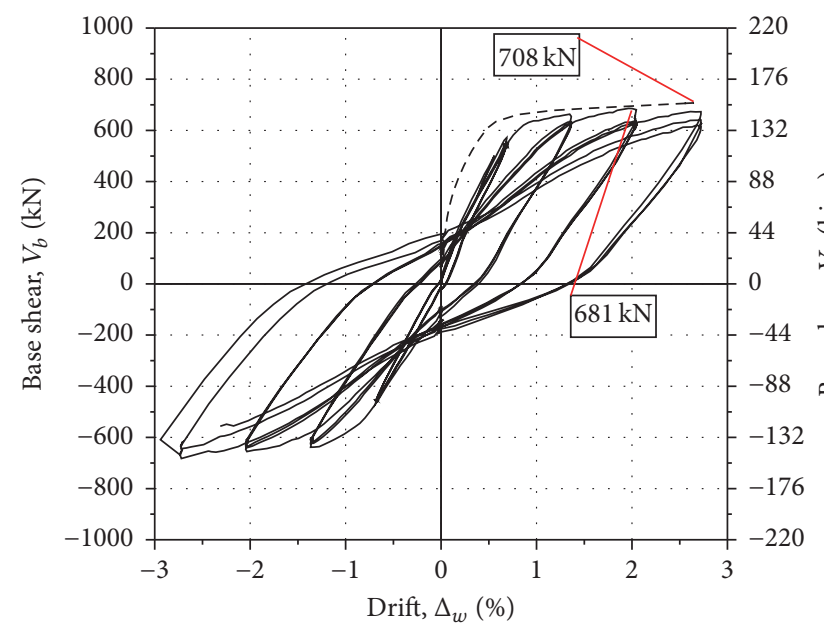

- MW-measured - - - MW-ABAQUS

(a) MW

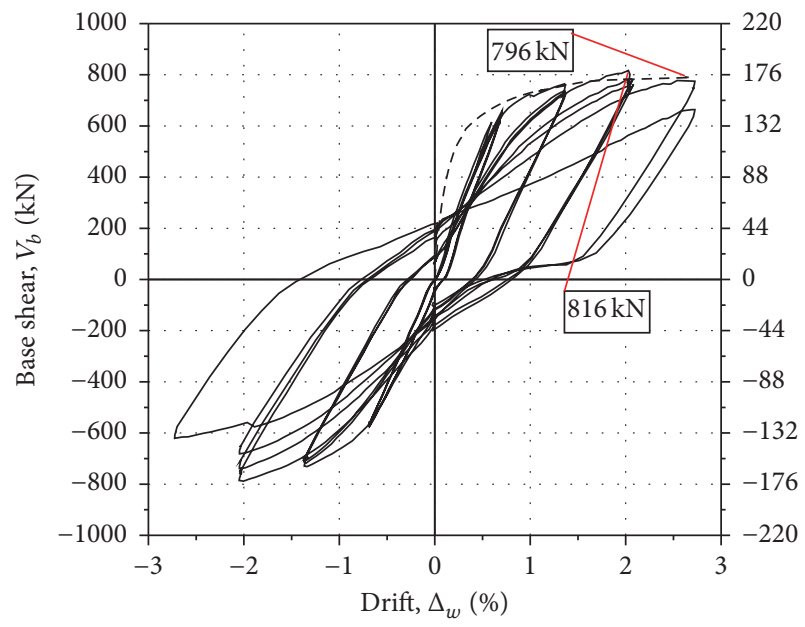

- HPWEM2-measured

- - - HPWEM2-ABAQUS

(c) HPWEM2

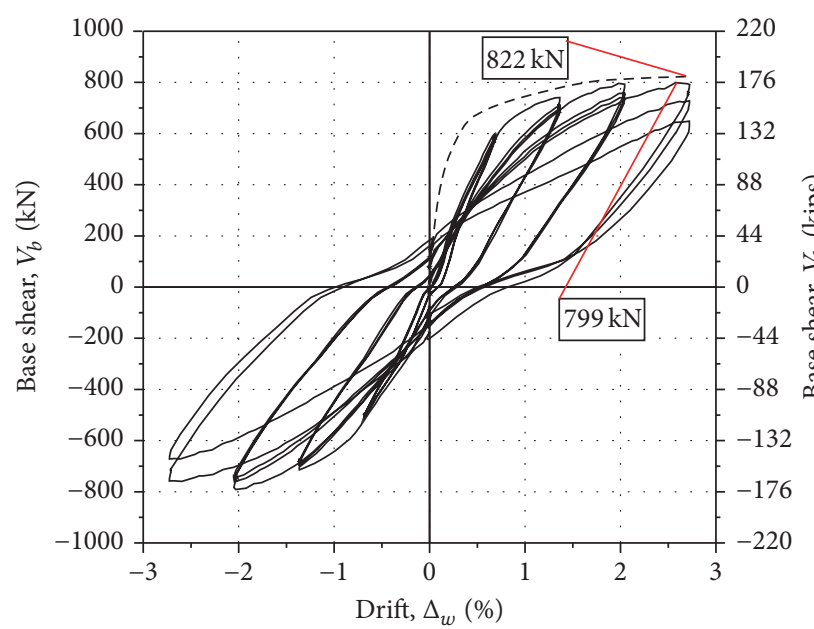

— HPWEM4-measured

- - - HPWEM4-ABAQUS

(e) HPWEM4

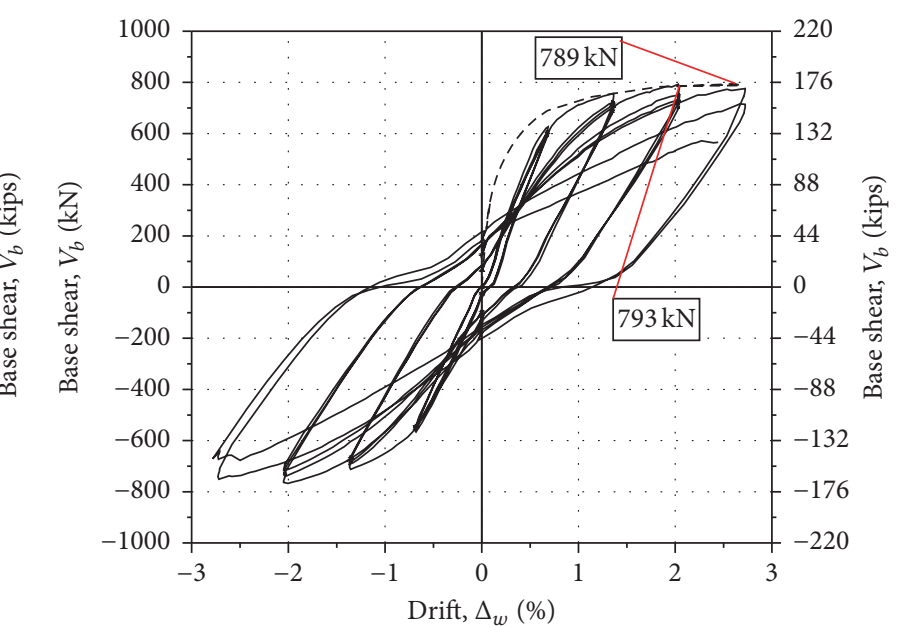

— HPWEM1-measured

- - - HPWEM1-ABAQUS

(b) HPWEM1

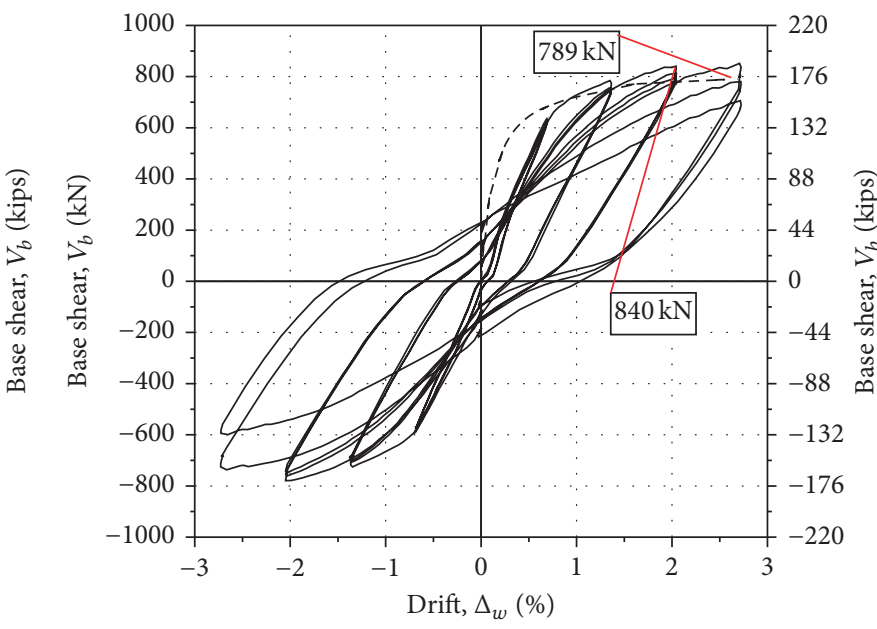

— HPWEM3-measured

- - - HPWEM3-ABAQUS

(d) HPWEM3

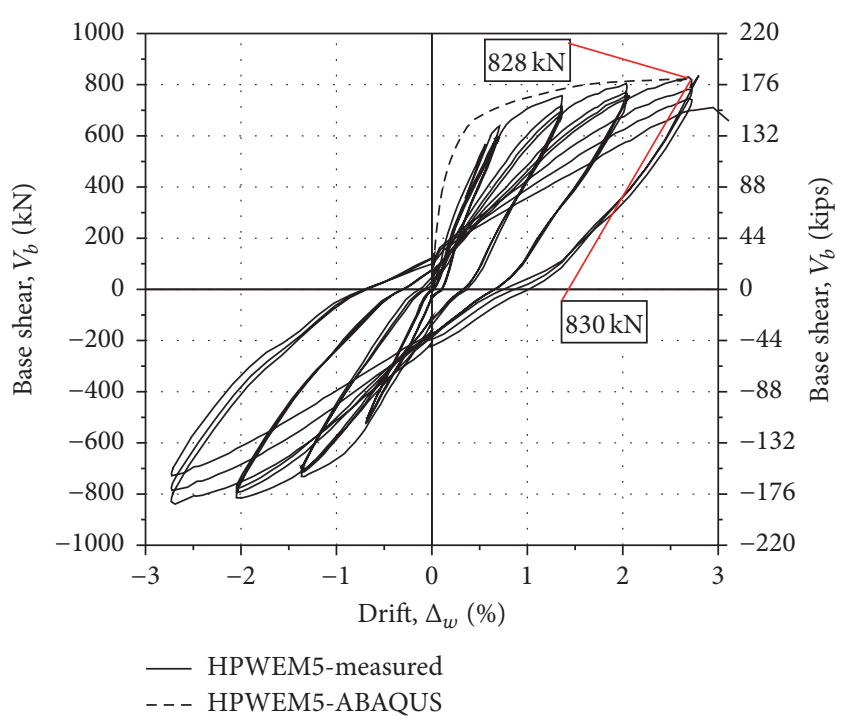

(f) HPWEM5

Figure 8: Continued. 


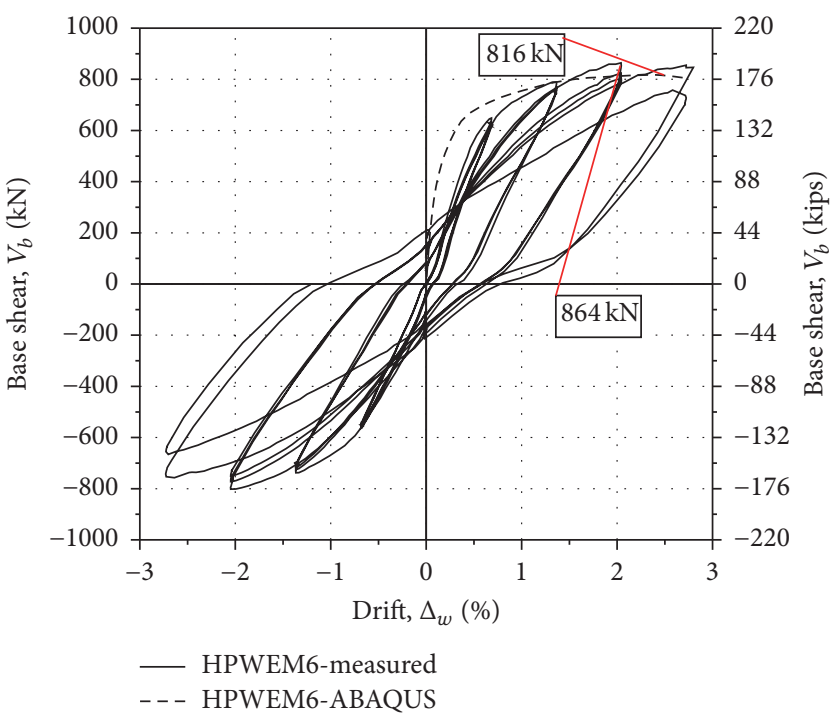

(g) HPWEM6

FIgURE 8: Hysteretic curves.

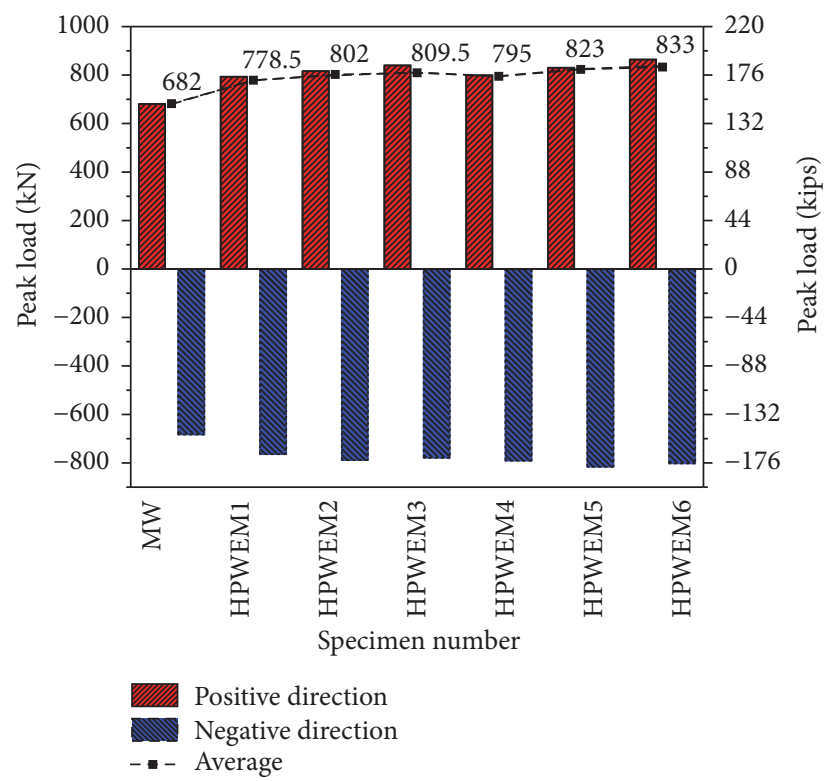

Figure 9: Measured strength.

HPWEM1-3 and Specimens HPWEM4-6, respectively, it could be found that the decrease of the amount of the strands and the shortening of the debond length of the connecting reinforcements improved the displacement ductility.

5.6. Energy Dissipation. The equivalent viscous damping ratio, defined as the ratio of energy dissipated in a half-cycle to the strain energy of an equivalent linear system divided by the constant $2 \pi$, was applied to evaluate the energy absorption capacity of the specimens. As shown in Figure 11, HPWEM specimens with smaller posttensioned forces in the unbonded strands (i.e., specimens HPWEM1-3) performed basically equal to or even better than Specimen MW in the aspect

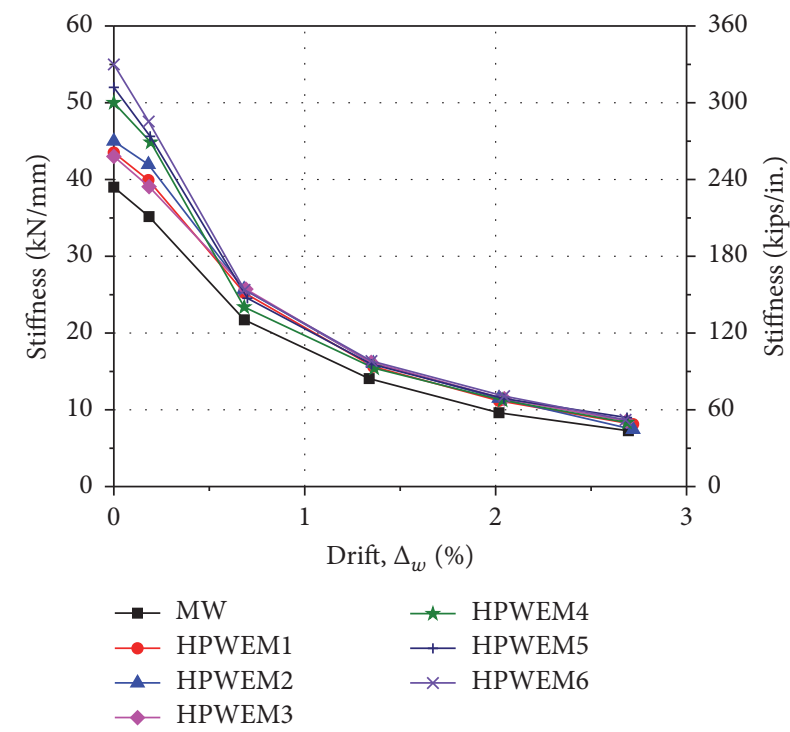

FIGURE 10: Stiffness degradation of the specimens.

of energy dissipation. Meanwhile, it was less obvious that the increase of the amount of strands weakened the energy absorption capacity of the specimen.

5.7. Residual Displacement. The measured residual displacements (i.e., the remaining lateral displacement at the load point upon the lateral force being zero) at the last cycle of each displacement loading increment of the specimens were shown in Figure 12. According with the design intention, the residual displacements of HPWEM specimens were reduced by contrast with that of the MW specimen. The clear influence of the involved variables including the number of strands and the debond length of grouted reinforcements on the 
TABLE 5: The ultimate stress of the unbonded strands.

\begin{tabular}{|c|c|c|c|c|c|c|}
\hline Ultimate stress & HPWEM1 & HPWEM2 & HPWEM3 & HPWEM4 & HPWEM5 & HPWEM6 \\
\hline Measured, MPa (ksi) & $1586.1(230)$ & $1132.1(164.2)$ & $767.5(111.3)$ & $1120.0(162.4)$ & $1105.7(160.3)$ & $1142.5(165.7)$ \\
\hline Analytical, $\mathrm{MPa}^{\mathrm{a}}$ (ksi) & $1628.8(236.2)$ & $1180.0(171.1)$ & $812.0(117.7)$ & $1152.6(167.1)$ & $1149.5(166.7)$ & $1151.1(166.9)$ \\
\hline Error $^{\mathrm{b}}$ & $2.69 \%$ & $4.23 \%$ & $5.80 \%$ & $2.91 \%$ & $3.96 \%$ & $0.75 \%$ \\
\hline
\end{tabular}

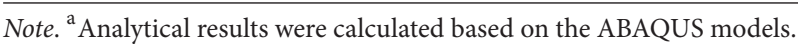

${ }^{\mathrm{b}}$ Error $=($ Measured - Analytical $) /$ Measured $\times 100 \%$.

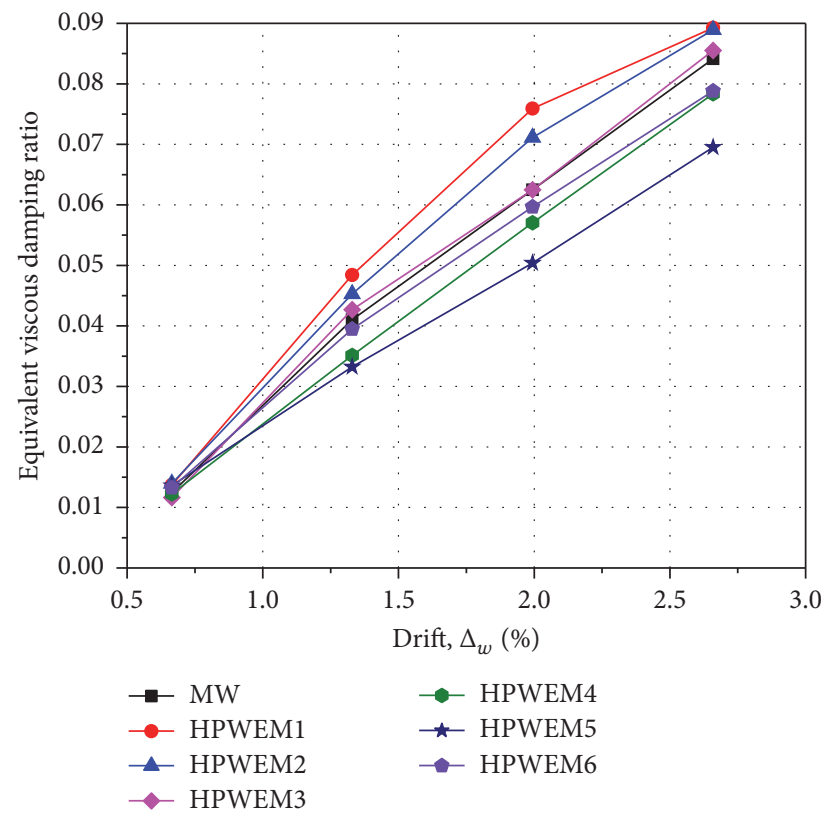

FIgURE 11: Energy dissipation curves.

residual displacement could not be obtained. However, by comparing Specimens HPWEM3 and HPWEM5, the residual displacement prominently decreased along with that the posttensioned force increased.

5.8. Steel Strain/Stress Behavior. The ultimate stress in the unbonded tendons is the key parameter to the strength of the specimen. The measured and analytical ultimate stresses are given in Table 5. The calculated results well conformed to the test results with minor errors. The ultimate stress decreased as the number of strands and was not obviously affected by the debond length of grouted reinforcements. Meanwhile, the ultimate stresses of all the specimens did not exceed the elastic limit of the strands (determined based on the material property as given in Table 1). It ensured that the unbonded tendon was capable of providing essential elastic restoring force to decrease the residual displacements.

The yielding of grouted reinforcements was effectively delayed due to the locally debond configuration. The yielding loads (the tensile strain of the exterior connecting reinforcement exceeded $0.31 \%$ ) of Specimens HPWEM1-6 were $500 \mathrm{kN}$ (112.4 kips), $525 \mathrm{kN}$ (118 kips), $550 \mathrm{kN}(123.6$ kips), $575 \mathrm{kN}$ (129.3 kips), $550 \mathrm{kN}$ (123.6 kips), and $500 \mathrm{kN}$ (112.4 kips), respectively, and Specimen MW otherwise yielded at $475 \mathrm{kN}$ (106.8 kips).

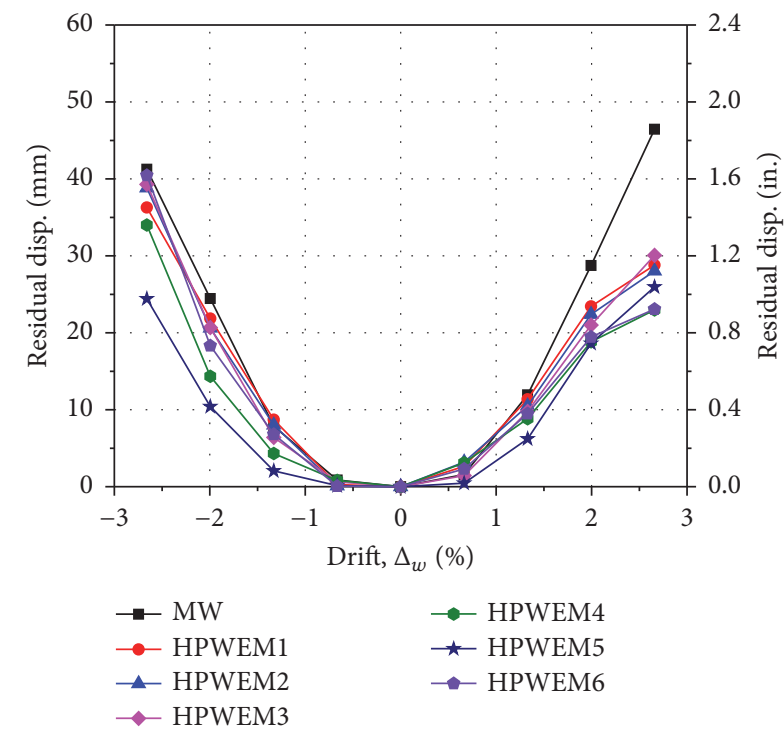

FIgURE 12: Residual displacement curves.

\section{Conclusions}

Quasistatic experimental investigations were conducted on HPWEM, considering design variables including the amount of strands and the debond length of grouted reinforcements. The results were then compared with the performance of a reference cast-in-place monolithic wall. The summary of the observations are as follows:

(1) HPWEM specimens (such as Specimens HPWEM13) were capable of providing strength, stiffness, energy dissipation, and ductility better than that of the monolithic wall specimen.

(2) The increase of the amount of the strands (i.e., enlargement of the area of the unbonded tendon) enhanced strength of the specimen and otherwise weakened energy-absorbing capacity as well as ductility of the specimen.

(3) The shortening of the debond length of grouted reinforcements enhanced the strength, initial stiffness, and ductility of the specimen.

(4) The increase of the posttensioned force of the unbonded tendons enhanced initial stiffness and selfcentering capacity of the specimen and otherwise reduced ductility and energy dissipation capacity of the specimen. 
(5) Overlapping welded closed stirrups with smaller length-to-width ratios improved the confinement property of the concrete, and thus the damage of the concrete at wall toes was obviously lightened.

(6) The yielding of grouted reinforcements was effectively delayed with wrapped length, and the minimum bond length of $350 \mathrm{~mm}$ (13.9 in., about 22 times the reinforcement diameter) in the high-strength grout was sufficient for the connecting reinforcements to develop the tensile strength.

(7) Analytical models by ABAQUS well replicated the skeleton curves of the specimens and the strand strain behavior.

\section{Competing Interests}

The authors declare that they have no competing interests.

\section{Acknowledgments}

This work was funded by National Natural Science Foundation of China (no. 51308289). The authors wish to acknowledge the funding agency for their support. Additional support provided by the ZHONGNAN Group, Inc., the Nanjing Tech University, and the Southeast University was also gratefully appreciated.

\section{References}

[1] M. J. N. Priestley, "Overview of PRESSS research program," PCI Journal, vol. 36, no. 4, pp. 50-57, 1991.

[2] K. A. Soudki, S. H. Rizkalla, and B. LeBlanc, "Horizontal connections for precast concrete shear walls subjected to cyclic deformations-part 1: mild steel connections," PCI Journal, vol. 40, no. 4, pp. 78-96, 1995.

[3] K. A. Soudki, S. H. Rizkalla, and R. W. Daikiw, "Horizontal connections for precast concrete shear walls subjected to cyclic deformations part 2: prestressed connections," PCI Journal, vol. 40, no. 5, pp. 82-96, 1995.

[4] B. J. Smith, Y. C. Kurama, and M. J. McGinnis, "Design and measured behavior of a hybrid precast concrete wall specimen for seismic regions," Journal of Structural Engineering, vol. 137, no. 10, pp. 1052-1062, 2011.

[5] B. J. Smith, Y. C. Kurama, and M. J. McGinnis, "Behavior of precast concrete shear walls for seismic regions: comparison of hybrid and emulative specimens," Journal of Structural Engineering, vol. 139, no. 11, pp. 1917-1927, 2013.

[6] T. Holden, J. Restrepo, and J. B. Mander, "Seismic performance of precast reinforced and prestressed concrete walls," Journal of Structural Engineering, vol. 129, no. 3, pp. 286-296, 2003.

[7] F. J. Perez, R. Sause, and S. Pessiki, "Analytical and experimental lateral load behavior of unbonded posttensioned precast concrete walls," Journal of Structural Engineering, vol. 133, no. 11, pp. 1531-1540, 2007.

[8] D. J. Marriott, S. Pampanin, A. Palermo, and D. Bull, "shaketable testing of hybrid post-tensioned precast wall systems with alternative dissipating solutions," in Proceedings of the 14th World Conference on Earthquake Engineering, International Association for Earthquake Engineering (IAEE), Chicago, Ill, USA, October 2008.
[9] American Concrete Institute (ACI), "Building code requirements for structural concrete and commentary," ACI 318-11, American Concrete Institute (ACI), Detroit, Mich, USA, 2011.

[10] R. Park, "Evaluation of ductility of structures and structural subassemblages from laboratory testing," Bulletin of the New Zealand National Society for Earthquake Engineering, vol. 22, no. 3, pp. 155-166, 1989. 

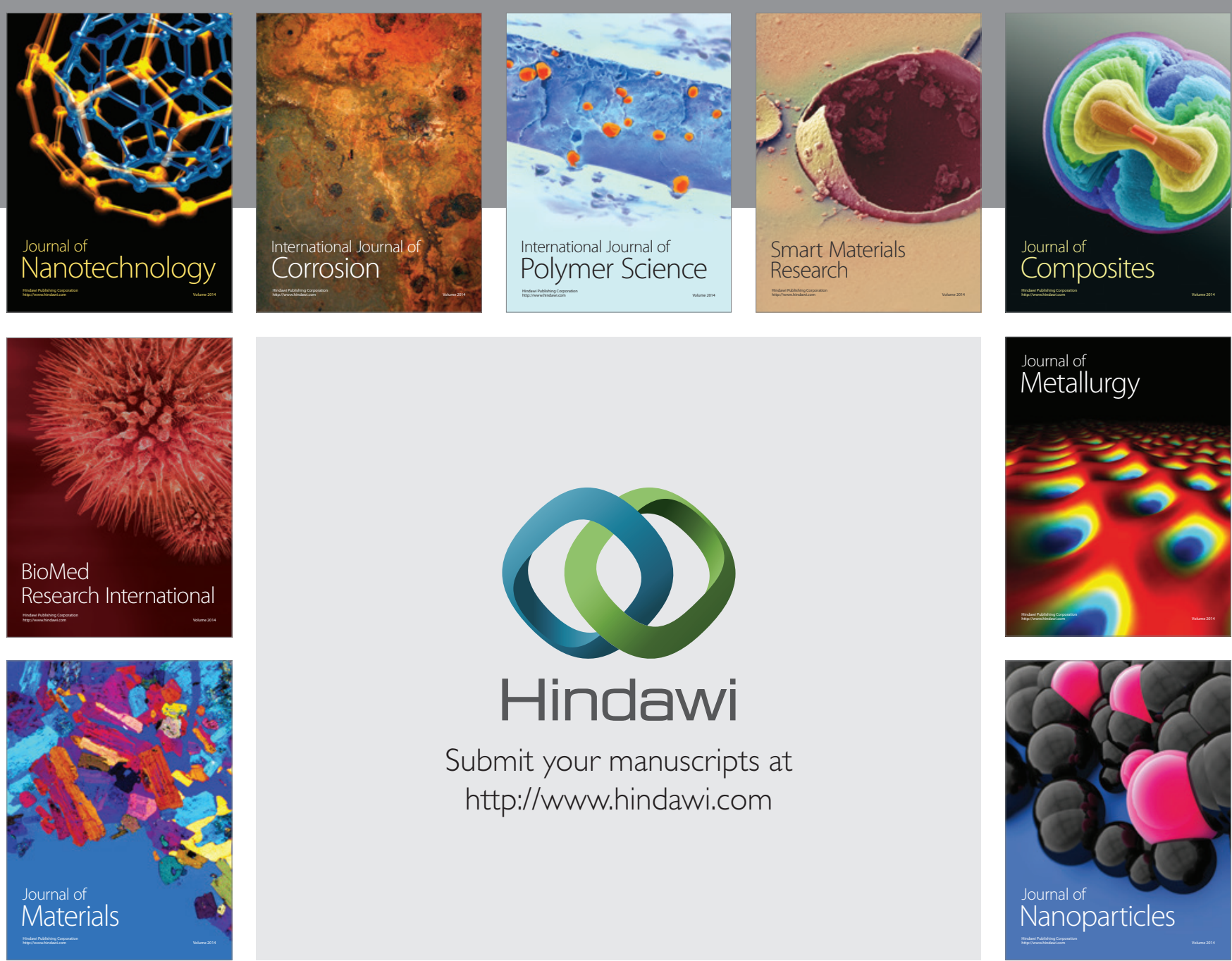

\section{Hindawi}

Submit your manuscripts at

http://www.hindawi.com

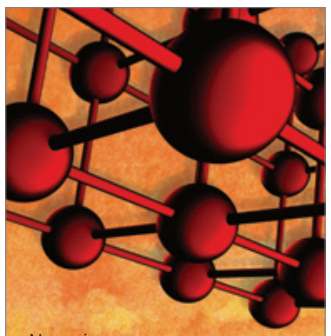

Materials Science and Engineering
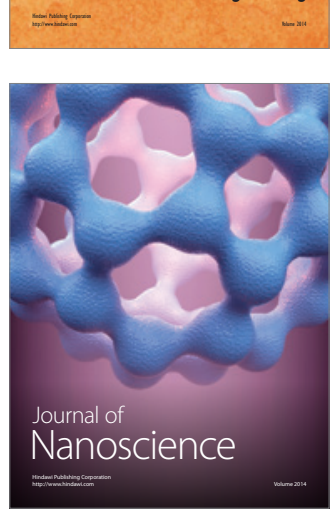
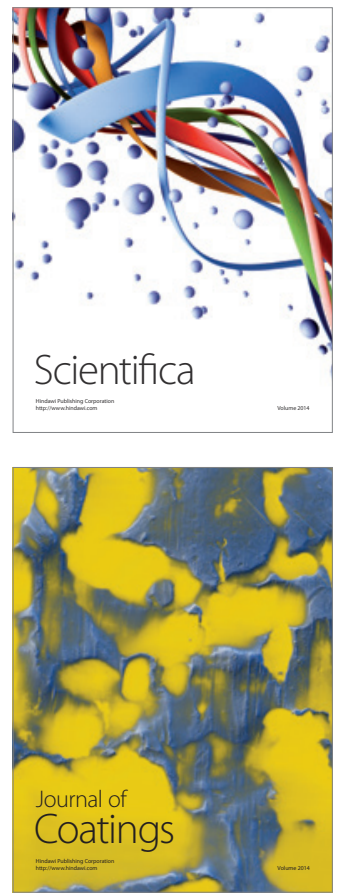
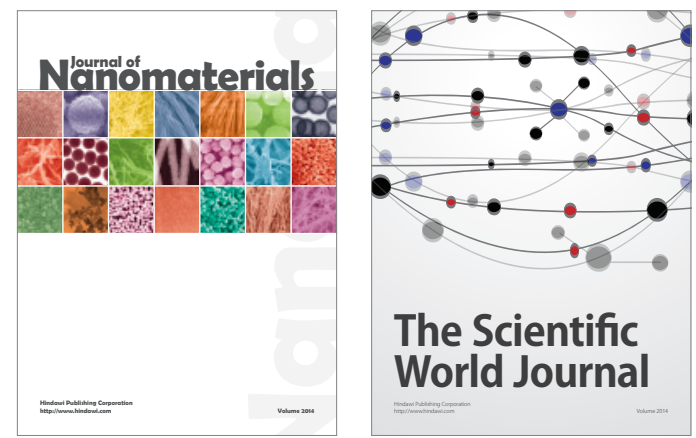

The Scientific World Journal
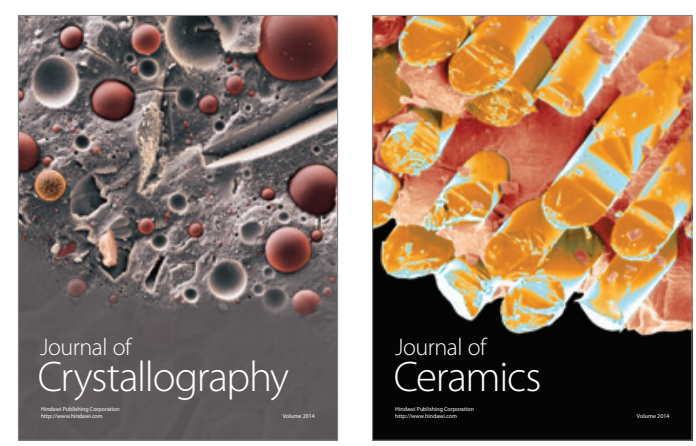
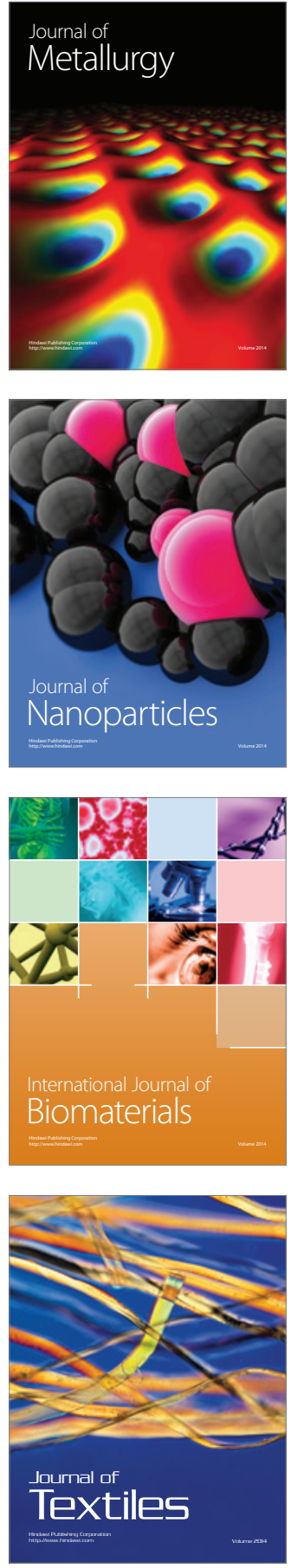